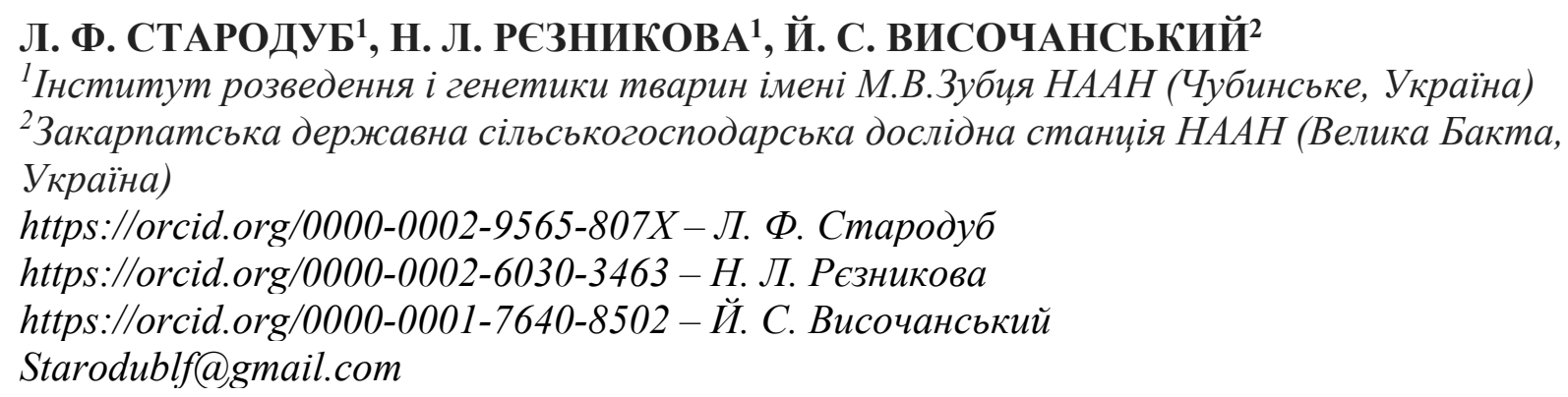

Тварини бурої карпатської породи відносяться до локальних малочисельних вітчизняних порід і перебувають в стані значного ризику. Маточне поголів я розводять лише у господарствах населення. За результатами цитогенетичного аналізу встановлено геномні порушення, анеуплоїдію, яка у помісних тварин у 2 раза вища (3,3\%) порівняно з чистопородними коровами бурої карпатської породи із статистично достовірною різницею середніх величин $(P>0,99)$. Відсутність структурних порушень хромосом у чистопородних тварин та їх помісей свідчить про низький ступінь соматичного мутагенезу.

Показники мікроядерного тесту (частка лімфоцитів з мікроядром 1,7-2,0\%о, двоядерних лімфочитів 1,5-2,7\%о та мітотичний індекс 4,8-5,5\%о відповідно) у помісних тварин вищі порівняно з чистопородними тваринами, проте не перевищують показники, характерні для виду Bos taurus.

Ключові слова: велика рогата худоба бурої карпатської породи, каріотип, анеуплоїдія, лімфоцит із мікроядром, двоядерний лімфоцит, мітотичний індекс

\title{
KARYOTYPAL VARIABILITY OF CARPATHIAN BROWN COWS
}

L. F. Starodub ${ }^{1}$, N. L. Reznikova ${ }^{1}$, J. S. Vysochansky ${ }^{2}$

${ }^{1}$ Insttute of Animal Breeding and Genetic nd. a. M.V.Zubets of NAAS (Chubynske, Ukraine)

${ }^{2}$ Transcarpathian State Agricultural Research Station of NAAS (Velyka Bakta, Ukraine)

Animals of the Brown Carpathian breed belong to the local small domestic breeds and are in a state of significant risk. The uterine population is bred only in households. According to the results of cytogenetic analysis established genomic disorders, aneuploidy, which in domestic animals is 2 times higher (3.3\%) compared to purebred cows of brown Carpathian breed with a statistically significant difference in mean values $(P>0.99)$. The absence of structural chromosome abnormalities in purebred animals and their crossbreeds indicates a low degree of somatic mutagenesis.

Indicators of the micronucleus test (the proportion of lymphocytes with a micronucleus of 1.7$2.0 \%$, dinuclear lymphocytes $1.5-2.7 \%$, and a mitotic index of $4.8-5.5 \%$, respectively) in domestic animals are higher than in purebreds animals, however, do not exceed those of the species Bos taurus. Keywords: Carpathian Brown cattle, karyotype, aneuploidy, lymphocyte with micronucleus, dinuclear lymphocyte, mitotic index

\section{КАРИОТИПИЧЕСКАЯ ИЗМЕНЧИВОСТЬ КОРОВ БУРОЙ КАРПАТСКОЙ ПОРОДЫ Л. Ф. Стародуб ${ }^{1}$, Н. Л. Резникова ${ }^{1}$, И. С. Высочанский ${ }^{2}$ \\ ${ }^{1}$ Институт разведения и генетики животных имени М.В.Зубиа НААН (Чубинское, Украина) 23 акарпатская государственная сельскохозяйственная опытная станция НААН (Большая Ба- кта, Украина)}


Животные бурой карпатской породы относятся к локальным малочисленным отечественным породам и находятся в состоянии значительного риска. Маточное поголовье разводят только в хозяйствах населения. По результатам ичтогенетического анализа установлено геномные нарушения, анеуплоидии, которые у помесных животных в 2 раза выше (3,3\%) по сравнению с чистопородным коровами бурой карпатской породы со статистически достоверной разницей средних величин $(P>0,99)$. Отсутствие структурных нарушений хромосом у чистопородных животных и их помесей свидетельствует о низкой степени соматического мутагенеза.

Показатели микроядерного теста (доля лимфоцитов с микроядром 1,7-2,0\%о, двухъядерных лимфоцитов 1,5-2,7\%о и митотический индекс 4,8-5,5\%о соответственно) у помесных животных выше по сравнению с чистопородными животными, однако не превышают показатели, характерные для вида Bos taurus.

Ключевые слова: крупный рогатый скот бурой карпатской породы, кариотип, анеуплоидия, лимфоцит с микроядром, двухъядерный лимфоцит, митотический индекс

Вступ. Бура карпатська порода великої рогатої худоби виведена на Закарпатті наприкінці XIX ст. й належить до порід молочно-м'ясного напряму продуктивності. Тварини сучасної породи є прямими нащадками стародавньої бурої карпатської худоби, поширеної свого часу в усій Середній Свропі. В районі Альп її називали бурою альпійською, в Швейцарії- швіцькою, в Австрії - горноінською і монтафонською, а в Німеччині - альгауською. Це були дрібні коротконогі тварини з густою довгою бурою й темно-бурою шерстю. У результаті тривалого міжпородного схрещування місцевої худоби із заводськими породами альпійського походження при спрямованому доборі щодо молочно-м'ясної продуктивності утворилася бура карпатська порода. У 1972 році ії було визнано породою [1].

Розводять буру карпатську породу у Закарпатській області та окремих гірських районах Івано-Франківської області. Масть бура, від світлого до темного відтінків. У дорослих тварин по спині тягнеться світло-сірий пояс. Носове дзеркало темне. Худоба має пропорційну будову тіла та міцну конституцію. Щодо розмірів, то їх можна віднести до порід середньої величини. Головна перевага бурої карпатської породи полягає в тому, що iï можна ефективно вирощувати на природних пасовищах - i в низинах, i в горах. Генетика цих тварин стійка до гострих інфекційних хвороб, вони добре пристосовані до місцевих умов, чутливі до поліпшення умов утримання та годівлі, а корови дають особливе молоко, яке використовується у виготовленні високоякісних твердих сирів та дитячого харчування. При цьому молочна продуктивність у бурої карпатської відносно невелика - 3000-4000 кг молока жирністю 3,6-3,7\%.

Сьогодні тварини бурої карпатської породи відносяться до локальних малочисельних вітчизняних порід. За проведеними розрахунками, відповідно до рекомендацій FAO, бура карпатська порода перебуває в стані значного ризику. Нині відсутнє жодне племінне господарство 3 розведення цієї породи. Маточне поголів 'я розводять лише у господарствах населення [3].

Фахівці закарпатської Асоціації бурої карпатської породи, яка входить до складу Федерації бурих порід Європи, розробили концепцію їі збереження, сформували банк генофонду і почали іiї генетичне дослідження. Цю роботу аграрії та науковці проводять за фінансової підтримки Продовольчої та сільськогосподарської організації ОOH, FAO [4].

Метою нашої роботи було дослідження мінливості каріотипу корів бурої карпатської породи.

Матеріали та методи досліджень. На цей час велика рогата худоба бурої карпатської породи знаходиться тільки у приватному секторі. Цитогенетичний аналіз, який був спрямований на встановлення каріотипової мінливості корів бурої карпатської породи, здійснювали на біологічному матеріалі, одержаному від тварин с. Нижні Ворота Воловецького району Закарпатської області у господарствах населення. Було досліджено корів бурої карпатської породи (16 гол.) та помісних тварин (11 гол.) (рис. 1). 


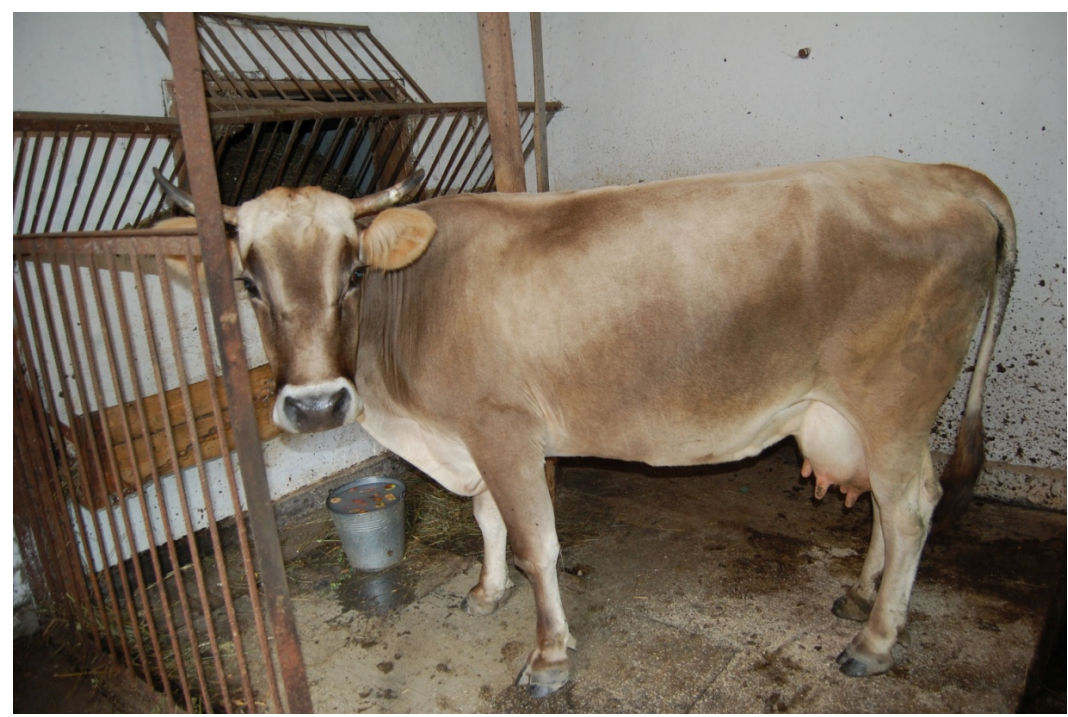

Рис. 1. Корова бурої карпатської породи

Цитогенетичні препарати отримували із лімфоцитів периферійної крові, взятої із яремної вени, використовуючи стандартну методику.

Для культивування клітин крові використовували середовище RPMI-1640, сироватку крові великої рогатої худоби (бажано ембріональної), антибіотик гентаміцин, мітоген - речовину, яка стимулює мітотичне ділення лімфоцитів у культурі (фітогемаглютинін типу Р). Суміш культивували в термостаті при температурі $+37^{\circ} \mathrm{C}$ впродовж 48 год. За дві години до фіксації в культуру вводили підігрітий до $37^{\circ} \mathrm{C}$ розчин колхіцину в кінцевій концентрації $0,3-$ 0,5 мкг/мл культурального середовища. Для гіпотонізації використовували свіжоприготовлений $0,55 \%$-ний розчин хлористого калію. Після закінчення гіпотонізації культуру центрифугували, надосадкову рідину зливали, а до осаду додавали охолоджену до $+4^{\circ} \mathrm{C}$ фіксуючу рідину, змішуючи одну частину льодяної оцтової кислоти з трьома частинами метилового (або етилового) спирту. Отримані препарати, після їх фарбування готовим барвником Гімза, аналізували на предмет хромосомної мінливості під імерсійним збільшенням мікроскопа у 1000 разів і мікрофотографували [5]. У кожної тварини аналізували 100 метафазних пластинок. На цих самих препаратах підраховували кількість двоядерних лімфоцитів (ДЯ), одноядерних лімфоцитів із мікроядрами (МЯ), мітотичний індекс (МI). Частоту ДЯ, МЯ, МІ вираховували в проміле (кількість на 1000 клітин) (рис. 2).

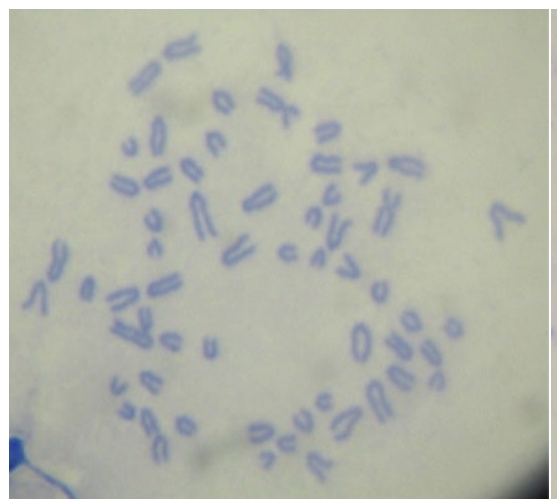

Норма каріотипу $2 \mathrm{n}=60$

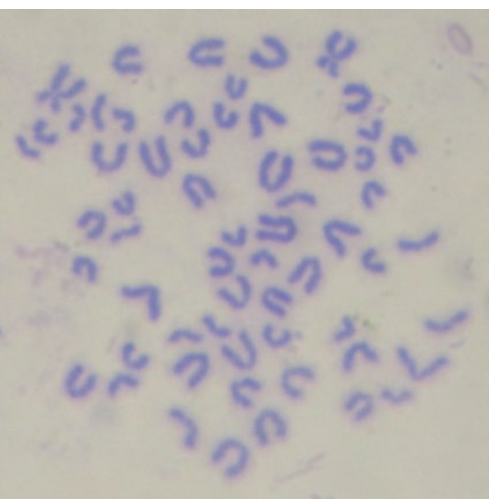

Анеуплоїдія $2 \mathrm{n}=56$

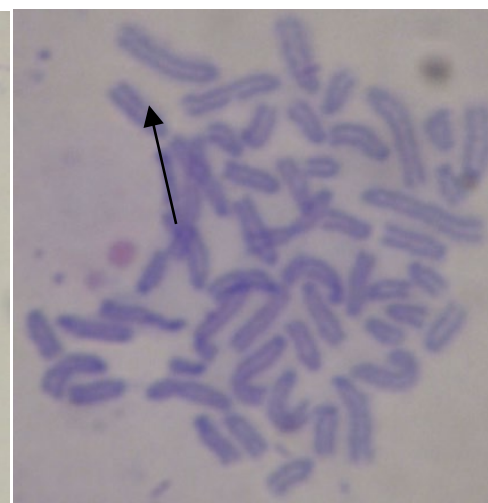

Хромосомний розрив

Рис. 2. Каріотипова мінливість корів бурої карпатської породи

Результати досліджень. При проведенні цитогенетичного моніторингу корів бурої карпатської породи протестованих тварин розділили на дві групи: чистопородні тварини бурої 
карпатської породи та помісні тварини. До помісей належали тварини, одержані від схрещу-

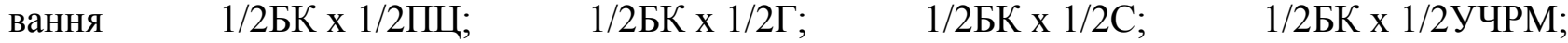
1/2БК х 3/12ПЦ х 3/12УЧРМ.

Одержані результати показали, що для чистопородних корів бурої карпатської породи були характерні кількісні та структурні порушення хромосом. Кількісні порушення, анеуплоїдія, становили $1,6 \%$ і були виражені, в основному, гіпоплоїдними клітинами $2 \mathrm{n}=56-58$. Кратне збільшення хромосом, поліплоїдія, виявлена не була.

Структурні порушення хромосом, хромосомні розриви, дорівнювали 0,76\%, що не перевищує спонтанний рівень хромосомної мінливості, характерний для цього виду (табл. 1).

\section{1. Мінливість каріотипу корів бурої карпатської породи та ӥх помісей, \% (M士m)}

\begin{tabular}{|c|c|c|c|c|}
\hline Порода & $\begin{array}{l}\text { Кількість } \\
\text { тварин (n) }\end{array}$ & Анеуплоїдія & Поліплоїдія & $\begin{array}{c}\text { Хромосомні } \\
\text { розриви }\end{array}$ \\
\hline Бура карпатська & 16 & $1,6 \pm 1,01 * *$ & - & $0,76 \pm 0,37$ \\
\hline 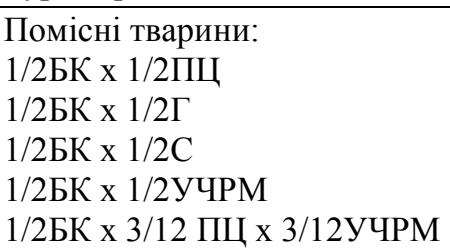 & 11 & $3,3 \pm 1,88 * *$ & - & - \\
\hline
\end{tabular}

\section{Примітка. $* *-P>0,99$}

Для помісних корів була характерна слідуюча каріотипова мінливість. Частота метафазних пластинок із анеуплоїдією дорівнювала 3,3\%, що відповідає спонтанному рівню цитогенетичної мінливості [6]. Кратне збільшення хромосомної мінливості, поліплоїдія, не проявилася. Структурні порушення хромосом були теж відсутні. Центромірне злиття 1/29 пари хромосом за Робертсонівським типом у корів двох груп виявлено не було.

Порівняльний аналіз каріотипової мінливості корів двох груп показав, що геномні порушення, анеуплоїдія, у помісних тварин у 2 раза вищі порівняно $з$ чистопородними коровами бурої карпатської породи. Різниця середніх величин за цією ознакою виявилася статистично достовірною при $\mathrm{P}>0,99$.

Невисокий рівень або відсутність структурних порушень хромосом у чистопородних тварин та їх помісей говорить про низький ступінь соматичного мутагенезу у досліджених корів. Таку думку підтверджують і інші дослідники. Зокрема, дослідження В. В. Дзіцюк підтверджують кращу пристосованість локальних порід до «жорстких» умов середовища та стабільність їх геному [7].

Мікроядерний тест у тварин бурої карпатської породи та їх помісей показав такі результати (табл. 2).

\section{2. Результати мікроядерного тесту корів бурої карпатської породи та їх помісей, \%о}

\begin{tabular}{|c|c|c|c|c|}
\hline Порода & $\begin{array}{c}\text { Кількість } \\
\text { тварин (n) } \\
\end{array}$ & $\begin{array}{l}\text { Лімфоцит } 3 \\
\text { мікроядром }\end{array}$ & $\begin{array}{c}\text { Двоядерний } \\
\text { лімфоцит }\end{array}$ & $\begin{array}{c}\text { Мітотичний } \\
\text { індекс }\end{array}$ \\
\hline Бура карпатська & 16 & $1,7 \pm 0,23$ & $1,5 \pm 0,24$ & $4,8 \pm 0,94$ \\
\hline 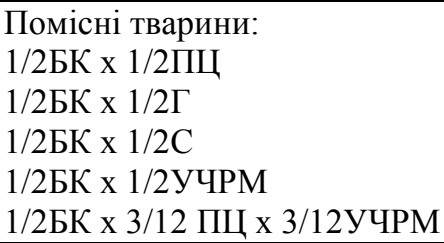 & 11 & $2,0 \pm 0,48$ & $2,7 \pm 1,18$ & $5,5 \pm 0,67$ \\
\hline
\end{tabular}

Всі показники мікроядерного тесту (частка лімфоцитів з мікроядром 1,7-2,0\%о, двоядерних лімфоцитів 1,5-2,7\%, та мітотичний індекс 4,8-5,5 \%о, відповідно) у помісних тварин по- 
рівняно з чистопородними тваринами бурої карпатської породи були вищі, проте 3 невірогідною достовірністю і не перевищували межу спонтанного рівня хромосомної мінливості за умов відсутності прямого генотоксичного впливу.

Отже, низький рівень соматичного мутагенезу та більш стабільний каріотип спостерігався у чистопородних тварин бурої карпатської породи порівняно з помісними.

\section{Висновки:}

Для чистопородних корів бурої карпатської породи та їх помісей були характерні кількісні та структурні порушення хромосом.

Геномні порушення, анеуплоїдія у помісних тварин у 2 раза вищі $(3,3 \%)$ порівняно 3 чистопородними коровами бурої карпатської породи із статистично достовірною різницею середніх величин $(\mathrm{P}>0,99)$.

Відсутність структурних порушень хромосом у чистопородних тварин та їх помісей говорить про низький ступінь соматичного мутагенезу.

Показники мікроядерного тесту (частка лімфоцитів з мікроядром 1,7-2,0\%о, двоядерних лімфоцитів 1,5-2,7\%о, та мітотичний індекс 4,8-5,5\% відповідно) у помісних тварин вищі порівняно з чистопородними тваринами.

Встановлено низький рівень соматичного мутагенезу та більш стабільний каріотип у чистопородних тварин бурої карпатської породи порівняно з помісними.

\section{БІБЛІОГРАФІЯ}

1. Заброварний О. М., Король В. І., Недава В. Ю. Бура карпатська порода. Ужгород : Карпати, 1971. $153 \mathrm{c.}$

2. Куркульські вісті. 2021. URL: https://kurkul.com/porody/24-bura-karpatska

3. Гладій М. В., Полупан Ю. П., Басовський Д. М., Вишневський Л. В., Ковтун С. І., Сидоренко О. В., Подоба Б. Є., Бірюкова О. Д., Рєзникова Н. Л., Войтенко С. Л., Джус П. П., Кузебний С. В., Шаран П. І., Кругляк О. В., Кругляк А. П., Мільченко Ю. В., Прийма С. В., Резнікова Ю. М., Мартинюк І. С., Жукорський О. М., Костенко О. І., Бащенко М. І., Кваша М. М., Романова О. В., Ладика В. І., Хмельничий Л. М., Вдовиченко Ю. В., Козирь В. С., Денисюк О. В., Катеринич О. О. Програма збереження генофонду локальних і зникаючих порід сільськогосподарських тварин в Україні на 2017-2025 роки. Суми : Сумський національний аграрний університет, 2018. 85 с.

4. Фахівці FAO допомогли зберегти буру карпатську породу корів на Закарпатті. Голос Каpnam. 2018. URL: https://milrua.info/uk/post/fahivci-fao-dopomogli-zberegti-buru-karpatskuporodu-koriv-na-zakarpatti

5. Шельов А. В., Дзіцюк В. В. Методика приготування метафазних хромосом лімфоцитів периферійної крові тварин. Методики наукових досліджень із селекиї, генетики та біотехнології у тваринництві. Київ : Аграрна наука, 2005. С. 210-213.

6. Бащенко М. І., Копилов К. В., Добрянська М. Л., Стародуб Л. Ф., Подоба Ю. В., Копилова К. В. Визначення генетичних аномалій у великої рогатої худоби : метод. рек. Чубинське, $2011.36 \mathrm{c}$.

7. Дзіцюк В. В. Хромосомний поліморфізм локальних порід сільськогосподарських тварин України. Науковий вісник Національного університету біоресурсів і природокористування $\mathrm{У}_{\text {- }}$ раїни. 2011. № 160. С. 300-303.

\section{REFERENCES}

1. Zabrovarnyy, O. M., V. I. Korol', and V. Yu. Nedava. 1971. Bura karpats'ka poroda - Brown Carpathian breed. Uzhhorod, Karpaty, 153 (in Ukrainian).

2. 2021. Kurkul's'ki visti - Kurkul news. 2021. URL: https://kurkul.com/porody/24-burakarpatska (in Ukrainian).

3. Hladiy, M. V., Yu. P. Polupan, D. M. Basovs'kyy, L. V. Vyshnevs'kyy, S. I. Kovtun, O. V. Sydorenko, B. Ye. Podoba, O. D. Biryukova, N. L. Ryeznykova, S. L. Voytenko, P. P. Dzhus, S. V. Kuzebnyy, P. I. Sharan, O. V. Kruhlyak, A. P. Kruhlyak, Yu. V. Mil'chenko, S. V. Pryyma, 
Yu. M. Reznikova, I. S. Martynyuk, O. M. Zhukors'kyy, O. I. Kostenko, M. I. Bashchenko, M. M. Kvasha, O. V. Romanova, V. I. Ladyka, L. M. Khmel'nychyy, Yu. V. Vdovychenko, V. S. Kozyr', O. V. Denysyuk, and O. O. Katerynych. 2018. Prohrama zberezhennya henofondu lokal'nykh i znykayuchykh porid sil's'kohospodars'kykh tvaryn v Ukrayini na 2017-2025 roky - The program of preservation of the gene pool of local and endangered breeds of farm animals in Ukraine for 2017-2025. Sumy, Sums'kyy natsional'nyy ahrarnyy universytet, 85 (in Ukrainian).

4. 2018. Fakhivtsi FAO dopomohly zberehty buru karpatsku porodu koriv na Zakarpatti. Holos Karpat - The voice of the Carpathians. URL: https://milrua.info/uk/post/fahivci-fao-dopomoglizberegti-buru-karpatsku-porodu-koriv-na-zakarpatti (in Ukrainian).

5. Shel'ov, A. V., and V. V. Dzitsyuk. 2005. Metodyka pryhotuvannya metafaznykh khromosom limfotsytiv peryferiynoyi krovi tvaryn - Method of preparation of metaphase chromosomes of lymphocytes of peripheral blood of animals. Metodyky naukovykh doslidzhen' iz selektsiyi, henetyky ta biotekhnolohiyi u tvarynnytstvi - Research methods in breeding, genetics and biotechnology in animal husbandry. Kyyiv, Ahrarna nauka, 210-213 (in Ukrainian).

6. Bashchenko, M. I., K. V. Kopylov, M. L. Dobryans'ka, L. F. Starodub, Yu. V. Podoba, and K. V. Kopylova. 2011. Vyznachennya henetychnykh anomaliy u velykoyi rohatoyi khudoby : metod. rek. - Determination of genetic anomalies in cattle : guidelines. Chubyns'ke, 36 (in Ukrainian).

7. Dzitsyuk, V. V. 2011. Khromosomnyy polimorfizm lokal'nykh porid sil's'kohospodars'kykh tvaryn Ukrayiny - Chromosomal polymorphism of local breeds of farm animals of Ukraine. Naukovyy visnyk Natsional'noho universytetu bioresursiv i pryrodokorystuvannya Ukrayiny - Scientific Bulletin of the national university of life and environmental sciences of Ukraine. 160:300-303 (in Ukrainian).

Одержано редколегією 07.04.2021 p.

Прийнято до друку 26.04.2021 p. 